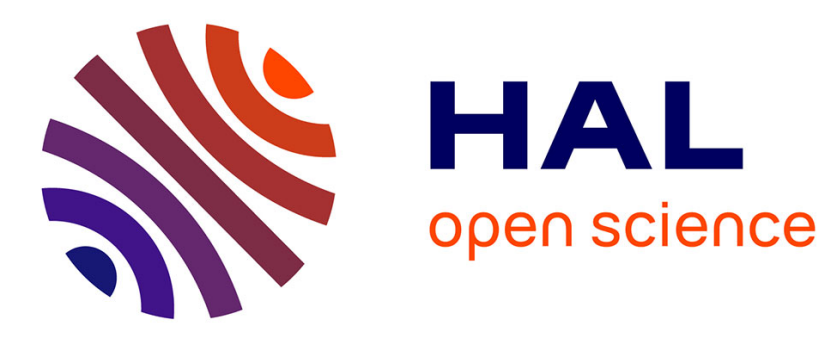

\title{
Kinetic analysis of butyrate transport in human colon adenocarcinoma cells reveals two different carrier-mediated mechanisms
}

Emilio Lecona, Nieves Olmo, Javier Turnay, Angélica Santiago-Gómez, Isabel López de Silanes, Myriam Gorospe, M. Antonia Lizarbe

\section{To cite this version:}

Emilio Lecona, Nieves Olmo, Javier Turnay, Angélica Santiago-Gómez, Isabel López de Silanes, et al.. Kinetic analysis of butyrate transport in human colon adenocarcinoma cells reveals two different carrier-mediated mechanisms. Biochemical Journal, 2007, 409 (1), pp.311-320. 10.1042/BJ20070374 . hal-00478774

\section{HAL Id: hal-00478774 \\ https://hal.science/hal-00478774}

Submitted on 30 Apr 2010

HAL is a multi-disciplinary open access archive for the deposit and dissemination of scientific research documents, whether they are published or not. The documents may come from teaching and research institutions in France or abroad, or from public or private research centers.
L'archive ouverte pluridisciplinaire HAL, est destinée au dépôt et à la diffusion de documents scientifiques de niveau recherche, publiés ou non, émanant des établissements d'enseignement et de recherche français ou étrangers, des laboratoires publics ou privés. 


\section{Kinetic analysis of butyrate transport in human colon adenocarcinona cells reveals two different carrier-mediated mechanisms}

Emilio Lecona*, Nieves Olmo*, Javier Turnay*, Angélica Santiago-Gómez*,Isabel López de Silanes $^{\dagger}$, Myriam Gorospe ${ }^{\dagger}$ and $\mathrm{M}^{\mathrm{a}}$ Antonia Lizarbe*

* Department of Biochemistry and Molecular Biology I, Faculty of Chemistry, Complutense University, 28040-Madrid, Spain

${ }^{\dagger}$ Laboratory of Cellular and Molecular Biology, National Institute on Aging-Intramural Research Program, National Institutes of Health, Baltimore, MD 21224, USA.

Short Title: Butyrate transport in colon adenocarcinoma cells

Keywords: anion exchanger, butyrate uptake, colon adenocarcinoma, monocarboxylate transporter, PKC activators and inhibitors, siRNA

Corresponding author: Prof. $\mathrm{M}^{\mathrm{a}}$ Antonia Lizarbe, Department of Biochemistry and Molecular Biology I, Faculty of Chemistry, Complutense University, 28040-Madrid, Spain. Tel. +34 91394 4256; Fax: +34 91394 4159; E-mail: lizarbe@bbm1.ucm.es

Abbreviations used: AE, anion exchanger; BSM, bisindolylmaleimide I; 4-CHC, $\alpha$-cyano-4hydroxycinnamate; DMEM, Dulbecco's modified Eagle's medium; DIDS, 4,4' diisothiocyanostilbene-2,2'-disulfonate; HBSS, Hanks' balanced salt solution; MCT, monocarboxylate transporter; PKC, protein kinase C; PMA, phorbol 12-myristate 13-acetate; SCFAs, short-chain fatty acids; SLC, solute-linked carrier 


\section{SYNOPSIS}

Butyrate has anti-tumorigenic effects on colon cancer cells, inhibits cell growth and promotes differentiation and apoptosis. These effects depend on its intracellular concentration which is regulated by its transport. We have analyzed butyrate uptake kinetics in human colon adenocarcinoma cells sensitive to the apoptotic effects of butyrate (BCS-TC2, Caco-2 and HT29), in butyrate resistant cells (BCS-TC2.BR2), and in normal colonic cells (FHC). The properties of transport were analyzed with structural analogues, specific inhibitors, and different bicarbonate and sodium concentrations. Two carrier-mediated mechanisms were detected: a low-affinity/high-capacity $\left(K_{\mathrm{m}}=109 \pm 16 \mathrm{mM}\right.$ in BCS-TC2 cells $)$ anion exchanger and a high-affinity/low-capacity $\left(K_{\mathrm{m}}=17.9 \pm 4.0 \mu \mathrm{M}\right.$ in BCS-TC2 cells $)$ protonmonocarboxylate cotransporter that was energy-dependent and activated via PKC $\delta$. All adenocarcinoma cells analyzed express MCT1, MCT4, ancillary protein CD147, and AE2. Silencing experiments show that MCT1, whose expression increases with butyrate-treatment in butyrate-sensitive cells, plays a key role in high-affinity transport. Low-affinity uptake was mediated by a butyrate-bicarbonate antiporter along with a possible contribution of AE2 and MCT4. Butyrate treatment increased uptake in a time- and dose-dependent manner in butyrate-sensitive but not in butyrate-resistant cells. The two butyrate-uptake activities in human colon adenocarcinoma cells enable butyrate transport at different physiological conditions to maintain cell functionality. The high-affinity/low-capacity transport functions under low butyrate concentrations and may be relevant for the survival of carcinoma cells in tumor regions with low glucose and butyrate availability as well as for the normal physiology of colonocytes. 


\section{INTRODUCTION}

Short-chain fatty acids (SCFAs) are produced by anaerobic bacterial fermentation of dietfiber within the large bowel. Among them, butyrate plays a key role in colonic epithelium homeostasis and represents the main fuel for colonocytes in vivo. Butyrate induces cell differentiation and apoptosis and regulates proliferation of mucosal epithelial cells, reducing the growth rate of colorectal cancer cells in culture [1, 2]. It is currently accepted that butyrate effects are mainly due to the regulation of the expression of specific genes through its activity as histone-deacetylase inhibitor [3]. SCFA uptake can be rate-limiting and deficiencies in the availability or utilization of butyrate have been implicated in the development of colitis and in colon carcinogenesis [4].

Different studies using several model systems indicate that SCFAs are transported into colonic epithelial cells by two different mechanisms: passive nonionic diffusion (unspecific component) of the undissociated SCFA form, and specific carried-mediated transport of SCFA anions. Although butyrate should be ionized at the physiological $\mathrm{pH}$ of the colonic lumen, the nonionic form of butyrate can exist due to the luminal acidic microclimate generated in the apical region of colonocytes by $\mathrm{H}^{+}$-secreting systems, as the $\mathrm{Na}^{+}-\mathrm{H}^{+}$ exchanger (isoforms 2\&3) [5]. Earlier work suggests that this is the main uptake mechanism [6], but later evidence supports a greater participation of carrier-mediated transport [7].

Carrier-mediated transport of the ionized form of butyrate has been described so far as: i) a nonelectrogenic $\mathrm{SCFA}^{-}-\mathrm{HCO}_{3}^{-}$antiporter, ii) an electroneutral $\mathrm{H}^{+}$-coupled monocarboxylate transporter, and iii) an electrogenic $\mathrm{Na}^{+}$-coupled monocarboxylate transporter. The SLC4 family mediates $\mathrm{Na}^{+}$-independent anion exchange and is involved in the electroneutral and reversible exchange of $\mathrm{Cl}^{-}$and $\mathrm{HCO}_{3}{ }^{-}$across the plasma membrane. The AE2 isoform (SLC4A2) has been described to mediate apical butyrate transport in HEK293 cells [8]. Experiments with membrane vesicles show an exchange butyrate- $\mathrm{HCO}_{3}{ }^{-}$ in apical and basolateral membranes from surface cells, but not from crypt cells, that is stimulated by a $\mathrm{pH}$ gradient $[9,10]$.

The proton-linked monocarboxylate transport is carried out by members of the SLC16 family. MCT1 (SLC16A1) and MCT4 (SLC16A3) require a monotopic ancillary protein, CD 147, for proper cell surface expression and butyrate transport. MCTs may transport one monocarboxylate with either a proton or sodium $[11,12]$, or exchange one monocarboxylate for another, via electroneutral transport, with a 1:1 stoichiometry. Monocarboxylate flux direction depends on the chemical gradients for $\mathrm{H}^{+}$and monocarboxylates across the 
membrane. Heterologous MCT1 expression has revealed its specificity for monocarboxylic acids such as pyruvate, L-lactate and acetate $[12,13]$ in association with a $\mathrm{Na}^{+}$-bicarbonate cotransporter to compensate for the proton influx [14]. It is inhibited by structural analogues, phloretin, tiol and amino reagents and derivatives of $\alpha$-cyanociannamate, with a lower sensitivity for 4,4'-diisothiocyanostilbene-2,2'-disulfonate (DIDS) and other stilbenes. MCT1 has been localized to the basolateral membranes of immature intestinal epithelial cells, whereas it appears in brush border membranes of absorptive cells. MCT4 is expressed in cells with a high glycolytic rate associated with hypoxic energy production [15], exhibiting a much lower affinity for most substrates and inhibitors than MCT1 [11].

SLC5A8 and SLC5A12 are sodium-coupled monocarboxylate transporters with a $\mathrm{Na}^{+}$:monocarboxylate stoichiometry of $4: 1$ for SCFAs [16]. They are very similar to MCTs in substrate selectivity but they are $\mathrm{Na}^{+}$-dependent. SLC5A12 is expressed in the small intestine (but not in colon) whereas SLC5A8 is expressed in the apical membranes of the colonic epithelium. Due to its location and lower substrate affinity, SLC5A12 is unlikely to participate in physiological SCFA absorption.

Poorly differentiated colon tumor cells grow in multilayer without polarization, what impairs the availability of oxygen and nutrients. Thus, transport mechanisms are likely to differ from those observed in colonocytes. There are only a few reports on butyrate transport in human colon adenocarcinoma cells, which mainly employ HT-29 cells [17] or polarized Caco-2 cells $[18,19]$ as a model system. Nevertheless, the latter cells more closely resemble the properties of small intestine epithelium [20], underscoring the need to further analyze this process in colon adenocarcinoma cells. Here, we examine butyrate transport in different human colon adenocarcinoma cell lines (butyrate-sensitive BCS-TC2 cells [21], butyrateresistant BCS-TC2.BR2 cells [22], both established in our laboratory, and HT-29 and Caco-2 cells), and investigate its regulation by butyrate. In addition, a human fetal normal colonic cell line (FHC cells [23]) has been included in the study. Data show that two carrier-mediated butyrate transport mechanisms coexist in colon carcinoma cells enabling uptake of butyrate at different concentrations. 


\section{EXPERIMENTAL}

\section{Cell lines and cell culture}

BCS-TC2 cells obtained from a poorly differentiated human colon adenocarcinoma show null tumorigenicity, low differentiation [21], and are sensitive to the apoptotic effects of butyrate [22]. The continuous growth of these cells in the presence of $2 \mathrm{mM}$ butyrate allowed the establishment of the BCS-TC2.BR2 cell subline, resistant to the apoptotic effects of butyrate, more differentiated and with intrinsic tumorigenicity [22]. Human colon adenocarcinoma cell lines HT-29 (HTB38) and Caco-2 (HTB37) and the fetal normal colonic cell line FHC (CRL1831) were obtained from the American Type Culture Collection. Cells were cultured in Dulbecco's modified Eagle's medium (DMEM) containing $4.5 \mathrm{~g} / 1$ glucose and supplemented with $5 \%(10 \%$ for Caco-2 cells) (v/v) heat-inactivated fetal calf serum, penicillin $(50 \mathrm{IU} / \mathrm{ml})$, streptomycin $(50 \mu \mathrm{g} / \mathrm{ml})$ and $2 \mathrm{mM}$ glutamine. FHC cells were cultured under the conditions recommended by the American Type Culture Collection. BCS-TC2.BR2 cells were grown in standard supplemented medium in the presence of $2 \mathrm{mM}$ butyrate (Sigma, Alcobendas, Spain) unless otherwise stated. Butyrate treatment was performed on pre-confluent cultures for 4 days at different butyrate concentrations, or at $4 \mathrm{mM}$ butyrate using different incubation times.

\section{$\left[{ }^{14} \mathrm{C}\right]$ Butyrate uptake measurements and kinetics}

Cells were seeded on 24-well plates at $10^{5} \mathrm{cells} / \mathrm{cm}^{2}$, and the assays performed 2 days later, when cultures were confluent. In Caco-2 cells, uptake was studied at least 5 days after reaching confluence. Cell monolayers were washed twice with $0.5 \mathrm{ml}$ of Hanks' balanced salt solution (HBSS) containing 10 mM HEPES, pH 7.5 (buffer A) and incubated in this buffer for $30 \mathrm{~min}$ at $37^{\circ} \mathrm{C}$ or, alternatively, pre-equilibrated $15 \mathrm{~min}$ at $4^{\circ} \mathrm{C}$. Buffer A was replaced with $0.5 \mathrm{ml}$ HBSS containing $10 \mathrm{mM}$ PIPES, pH 6.5 (buffer B) and $\left[1-{ }^{14} \mathrm{C}\right]$ butyrate (American Radiolabeled Chemicals, St. Louis, MO; $56 \mathrm{mCi} / \mathrm{mmol}, 1 \mathrm{mCi} / \mathrm{ml}$ ) and cells were incubated for $30 \mathrm{~min}$ at 37 or $4^{\circ} \mathrm{C}$. Cells were then washed twice with ice-cold buffer $\mathrm{B}$, $\left[1-{ }^{14} \mathrm{C}\right]$ butyrate was extracted with $1 \mathrm{ml}$ ethanol for $30 \mathrm{~min}$, and radioactivity was measured. All values were corrected by subtracting time zero radioactivity. Protein concentration was determined in each well after butyrate extraction by solubilization of the monolayers with 0.1 $\mathrm{MNaOH}$ in $\mathrm{PBS}$ and using the $\mathrm{D}_{\mathrm{C}}$ Protein Assay (Bio-Rad, Madrid, Spain).

Butyrate uptake kinetics were determined by adding unlabeled butyrate to the standard uptake buffer containing constant tracer amounts of $\left[1-{ }^{14} \mathrm{C}\right]$ butyrate. Kinetic data were either analyzed for simple Michaelis-Menten kinetics using hyperbolic nonlinear 
regression analysis after subtraction of butyrate uptake at $4{ }^{\circ} \mathrm{C}$, or fitted to an equation considering a hyperbolic transport with an added linear component (using only uptake data at $\left.37^{\circ} \mathrm{C}\right): \mathrm{v}_{0}=\left(\mathrm{V}_{\max } \cdot[\mathrm{B}] /\left(\mathrm{K}_{\mathrm{m}}+[\mathrm{B}]\right)\right)+\left(\mathrm{K}^{\prime} \cdot[\mathrm{B}]\right)$, where $[\mathrm{B}]$ is butyrate concentration and $\mathrm{K}^{\prime}$ is the slope of the linear component.

\section{Competition studies and treatment with inhibitors and activators}

For competition experiments, acetate, L-lactate and unlabeled butyrate were used. For studies employing transport inhibitors, a 15 -min pre-treatment was carried out in buffer B at $37^{\circ} \mathrm{C}$ with the different agents (4-CHC, NaHS, and DIDS; Sigma). The effects of bicarbonate, sodium, antimycin A, mannitol, amiloride, acetazolamide, phorbol 12-myristate 13-acetate (PMA), ingenol-3-angelate (all from Sigma), rottlerin, and bisindolylmaleimide I (BSM) (both from Calbiochem, Darmstadt, Germany) were also analyzed.

\section{Gene silencing using interference RNA}

MCT1 gene silencing was performed on BCS-TC2 cells using two different synthetic small interfering RNAs (siRNAs) [24]: sil-sense GCAGUAUCCUGGUGAAUAAdTdT in a duplex with sil-antisense UUAUUCACCAGGAUACUGCdTdG, and si2-sense CGAAUAAAGAUAGGAUUGGdTdT in a duplex with si2-antisense CCAAUCCUAUCUUUAUUCGdTdT, all purchased from Sigma-Proligo. A scrambled siRNA was also added as a control. Transfection of siRNAs was carried out using Escort IV (Sigma) according to the manufacturer's instructions. After transfection, the cells were cultured for $72 \mathrm{~h}$ under standard culture conditions and the change of MCT1 expression was analyzed using Western blot. The uptake of $\left[{ }^{14} \mathrm{C}\right]$ butyrate in transfected cells was examined in parallel cultures prepared under identical conditions.

\section{Other procedures}

RT-PCR analysis was carried out using total RNA [isolated using the ToTALLY RNA kit from Ambion (Austin, TX)] and the SuperScript One-Step RT-PCR kit (Invitrogen, Carlsbad, CA) using gene-specific primer pairs (Table 1). Western blot analysis was carried out as described [22] using polyclonal anti-human MCT-1 antibody (US Biological, Swampscott, MA) or monoclonal anti-human vinculin (clone hVIN-1; Sigma), and peroxidase-conjugated rabbit anti-goat IgG (Jackson Immunoresearch, West Grove, PA) or goat anti-mouse IgG (Bio-Rad). Signals were visualized using an ECL kit (Amersham-Pharmacia-Biotech, Buckinghamshire, UK) on a LAS-3000 detector (Fujifilm, Düsseldorf, Germany) and 
densitometric analysis was carried out using Multi Gauge v3.0 software (Fujifilm). Alkaline phosphatase activity (a marker of colonic epithelium differentiation) was measured in cell extracts obtained as described [25] using the ALP 10 kit (Sigma).

\section{Statistical analysis}

Butyrate uptake data were obtained from at least three independent experiments with triplicate samples and represent mean values $( \pm \mathrm{SD} ; 95 \%$ confidence interval). Differences between the mean values were analyzed using a two-tailed Student's $t$-test; statistical significance was considered to be achieved at the $p<0.05$ level.

\section{RESULTS}

In preliminary experiments, $\left[{ }^{14} \mathrm{C}\right]$ butyrate transport was shown to be linear in $30-\mathrm{min}$ incubation periods, in all cell lines at the range of concentrations employed (not shown). The effect of butyrate concentration on transport was analyzed at $4^{\circ} \mathrm{C}$ and $37^{\circ} \mathrm{C}$. At $4^{\circ} \mathrm{C}$ a linear variation was observed whereas at $37^{\circ} \mathrm{C}$ both saturable and non-saturable components were detected; the specific uptake was determined by subtracting the non-saturable component at $4^{\circ} \mathrm{C}$ from the global uptake at $37^{\circ} \mathrm{C}$ or after direct non-linear regression of the data obtained at $37^{\circ} \mathrm{C}$ as described under Experimental.

\section{$\left[{ }^{14} \mathrm{C}\right]$ Butyrate uptake kinetics and characterization in BCS-TC2 cells}

Uptake kinetics was studied in BCS-TC2 cells using 10 to $150 \mathrm{mM}$ butyrate. Figure 1A shows the experimental transport data obtained both at $4{ }^{\circ} \mathrm{C}$ and $37^{\circ} \mathrm{C}$. In addition, the saturable (hyperbolic) and non-saturable (linear) uptake components at $37^{\circ} \mathrm{C}$ obtained after fitting are shown; the linear component was quite similar to experimental data obtained at $4^{\circ} \mathrm{C}$. The saturable transport showed an apparent Michaelis constant of $109 \pm 16 \mathrm{mM}$ with a maximum uptake velocity of $90 \pm 6 \times 10^{-4} \mathrm{nmol} \cdot \mu \mathrm{g}^{-1} \cdot \mathrm{min}^{-1}$. These parameters agree with a lowaffinity and high-capacity system. Butyrate transport was characterized at $20 \mathrm{mM}$ butyrate (Figure 1B). The uptake of radiolabeled butyrate was almost completely abolished by 200 mM unlabeled butyrate or reduced by $\sim 30 \%$ after addition of the structural analogue L-lactate (200 $\mathrm{mM})$. No modifications in the specific transport were detected after raising the osmolarity (40 mM mannitol) or in the presence of the thiol-reagent NaHS or the inhibitor of 
MCT-transporters, $\alpha$-cyanocinnamate derivative 4-CHC (Figure 1B). In contrast 1 or $2 \mathrm{mM}$ DIDS increased transport $\sim 2.3$-fold. As DIDS blocks several anion exchangers in the membrane [8], we analyzed the effect of their main substrate: bicarbonate. Forty and $120 \mathrm{mM}$ bicarbonate inhibited $\sim 75 \%$ of specific butyrate uptake (Figure $1 \mathrm{~B}$ ) and the presence of bicarbonate partly prevented the DIDS-stimulated butyrate uptake (not shown), suggesting a DIDS-insensitive butyrate-bicarbonate transport at these butyrate concentrations. Additionally, the absence of sodium did not significantly modify butyrate transport.

A detailed analysis of butyrate transport at concentrations below $5 \mathrm{mM}$ (Figure 2A; Table 2) showed an additional hyperbolic specific component with an apparent $\mathrm{K}_{\mathrm{m}}$ of 17.9 $\mu \mathrm{M}$ and a maximum uptake velocity of $0.71 \times 10^{-4} \mathrm{nmol} \cdot \mu \mathrm{g}^{-1} \cdot \mathrm{min}^{-1}$. The linear component at $37^{\circ} \mathrm{C}$ was again quite similar to the uptake kinetics at $4^{\circ} \mathrm{C}$ (not shown). Characterization of this high-affinity/low-capacity transport is shown in Figure 2(B\&C). The $\mathrm{pH}$ dependence and the effect of different agents were analyzed at $40 \mu \mathrm{M}$ butyrate. A decrease in extracellular $\mathrm{pH}$ from 7.5 to 5.5 increased butyrate transport in BCS-TC2 cells by $61 \%$ (Figure 2B). Increased osmolarity (40 mM mannitol) had no effect on transport whereas treatment with the structural analogues acetate and L-lactate inhibited the uptake by 53 and $85 \%$, respectively, and $20 \mathrm{mM}$ unlabeled butyrate abolished (99\% inhibition) transport. Treatment with 4-CHC and NaHS each inhibited uptake significantly (up to $90 \%$ for $5 \mathrm{mM} 4-\mathrm{CHC}$, and $84 \%$ for $2 \mathrm{mM} \mathrm{NaHS}$ ), while DIDS did not significantly change butyrate transport (Figure 2C). Bicarbonate inhibited butyrate uptake in a concentration-dependent manner (120 mM bicarbonate totally prevented the uptake; Figure 2C), indicating that a different sensitivity to bicarbonate was displayed at high or low butyrate concentrations. Additionally, the absence of sodium dramatically reduced butyrate uptake. The $\mathrm{Na}^{+}-\mathrm{H}^{+}$exchanger inhibitor amiloride $(2 \mathrm{mM})$ did not affect butyrate uptake whereas a 16\% inhibition was achieved using $4 \mathrm{mM}$ acetazolamide, a carbonic anhydrase inhibitor that blocks the $\mathrm{Na}^{+}$-bicarbonate cotransporter. The incubation of the cells with both inhibitors at the indicated concentrations induced a synergic reduction $(36 \%)$ of butyrate uptake.

Together, these results support the existence of two specific carrier-mediated transport mechanisms in BCS-TC2 cells kinetically characterized as low-affinity/high-capacity and high-affinity/low-capacity transporters, being the latter described and characterized here for the first time. 


\section{High-affinity/low-capacity butyrate transport is present in other human colon carcinoma cells and in normal colon cells}

To extend the relevance of the analysis, we have also studied the presence of the highaffinity/low-capacity transport in the widely used HT-29 and Caco-2 human colon adenocarcinoma cells, as well as in butyrate-resistant BCS-TC2.BR2 cells. In addition to a low-affinity/high capacity transport (not shown), these cell lines displayed the highaffinity/low-capacity butyrate uptake at concentrations below $5 \mathrm{mM}$ (Figure 3A). Figure 3B shows a detail of transport kinetics below $200 \mu \mathrm{M}$ butyrate. The four cell lines presented apparent Michaelis constants $\left(K_{\mathrm{m}}\right)$ in the micromolar range without significant differences; in contrast, the maximum uptake velocitiy $\left(V_{\max }\right)$ differed among the cell lines (Table 2$)$. The $V_{\max }$ value was highest for confluent Caco-2 cells and lowest for BCS-TC2 cells. Butyrateresistant BCS-TC2.BR2 cells exhibited a 1.4-fold higher $V_{\max }$ than the parental cells. HT29 cells showed an intermediate value between Caco-2 and BCS-TC2.BR2 cells.

Butyrate uptake was also measured in human normal colonic cells (FHC). Figure 3C shows uptake kinetics at $37^{\circ} \mathrm{C}$ at concentrations below $200 \mu \mathrm{M}(5 \mathrm{mM}$ in the insert) and the nonlinear regression with the hyperbolic and the non-saturable components described above in colon adenocarcinoma cells. $K_{\mathrm{m}}$ and $V_{\max }$ values are similar to those obtained for HT-29 cells (Table 2).

Even though Caco-2 cells show the highest alkaline phosphatase activity values and $V_{\max }$ for butyrate transport among colon adenocarcinoma cells, no clear relationship between differentiation and high-affinity transport was found (Table 2). In addition, FHC cells showed the highest differentiation degree according to their alkaline phosphatase activity, in agreement with a normal colon cell phenotype. However, these cells presented kinetic parameters similar to those of low-differentiated adenocarcinoma cells.

\section{Characterization of butyrate transport in butyrate-resistant BCS-TC2.BR2 cells}

We have characterized butyrate transport in butyrate-resistant BCS-TC2.BR2 cells (Figure 4). Regarding the low-affinity/high-capacity transport, the main differences with parental butyrate-sensitive cells were: i) higher inhibition by lactate, ii) inhibition of the transport by 5 mM 4-CHC ( $\sim 50 \%)$, iii) increase in DIDS activation ( $\sim 3$-fold), and iv), lower inhibition by bicarbonate (Figure 4A). When the high-affinity/low-capacity butyrate transport was analyzed, the most significant differences with BCS-TC2 cells were found in the effect of bicarbonate, as $40 \mathrm{mM}$ bicarbonate did not inhibit butyrate transport, and $120 \mathrm{mM}$ only 
inhibited it by $30 \%$ (Figure 4B). A slightly stronger inhibition was detected with structural analogues.

In BCS-TC2.BR2 cells, butyrate transport also increased (47\%) when the $\mathrm{pH}$ was lowered from 7.5 to 5.5; the uptake at all $\mathrm{pH}$ values was higher in the butyrate-resistant cells compared to BCS-TC2 cells, although this difference was not significant at $\mathrm{pH} 5.5$ (not shown).

\section{Energy requirements of butyrate transport and effect of PKC inhibitors and activators}

The energy dependence of the high-affinity/low-capacity butyrate transport was analyzed in BCS-TC2 and BCS-TC2.BR2 cells by inhibiting the respiratory chain electron transfer complex III with antimycin A. Butyrate transport in both cell lines was deemed to be an energy-dependent process as it was significantly inhibited by this agent (Figure 5). Similarly, treatment with the specific $\mathrm{PKC} \delta$ inhibitor rottlerin significantly decreased butyrate transport in both cell lines, although BCS-TC2.BR2 cells were more refractory to the inhibition (Figure 5). The general PKC competitive inhibitor BSM only reduced butyrate uptake when used at $250 \mathrm{nM}$ (close to the $\mathrm{Ki}$ value of $\mathrm{PKC} \delta$ ). Activation of PKC had the opposite effect; an increase to around $150 \%$ butyrate uptake was achieved using the general PKC activator PMA at $1 \mu \mathrm{M}$ or the specific PKC $\delta$ activator ingenol-3-angelate at $50 \mathrm{nM}$ in both cell lines (Figure 5).

\section{Effect of butyrate treatment on $\left[{ }^{14} \mathrm{C}\right]$ butyrate uptake}

We analyzed the time- and dose-dependent effects of butyrate treatment on the highaffinity/low-capacity $\left[{ }^{14} \mathrm{C}\right]$ butyrate uptake (Figure $6 \mathrm{~A}$ ). A steady increase in uptake was detected in BCS-TC2 cells treated with $4 \mathrm{mM}$ butyrate for different times $(62 \%$ increase after 4 days treatment), while BCS-TC2.BR2 cells showed no increase over time. For HT29 cells, after a small decrease, an increase in transport is also observed (48\%), while no significant modification takes place in Caco-2 cells (not shown).

After 4 days of treatment with different butyrate concentrations, a dose-dependent increase in butyrate uptake was seen in BCS-TC2 cells ( $90 \%$ increase at $10 \mathrm{mM}$ butyrate). BCS-TC2.BR2 cells showed no significant changes with up to $4 \mathrm{mM}$; but a $58 \%$ increase was observed at $10 \mathrm{mM}$ (Figure 6A). HT29 and Caco-2 cells showed a small increase and decrease, respectively (not shown). 


\section{Detection of potential butyrate transporters by RT-PCR}

Total RNA was obtained from the different cell lines and from butyrate-treated BCS-TC2 cells, and the expression levels of mRNAs encoding MCT1, MCT4, AE2, SLC5A8, SLC5A12, and CD147 were assessed using gene-specific primers (Table 1). No differences were detected in the expression of AE2 or CD147 among the cells lines. On the other hand, SLC5A8 was only expressed in Caco-2 cells, and SLC5A12 in Caco-2 and butyrate-treated BCS-TC2 cells. MCT1 was expressed in all the cell lines studied; the lowest expression was observed in BCS-TC2 cells followed by BCS-TC2.BR2. MCT4 was also expressed in all of the cell lines with maximal expression in BCS-TC2 cells and very low in Caco-2 cells (Figure 7A).

\section{Role of MCT1 in high-affinity/low-capacity butyrate uptake}

The characteristics of high-affinity/low-capacity butyrate uptake (effect of structural analogues, inhibitors and $\mathrm{pH}$ ) suggest the potential involvement of MCT1 in this transport. To verify this hypothesis, MCT1 expression was silenced using two different specific siRNAs. BCS-TC2 cells were transfected with increasing amounts of MCT1-directed siRNAs up to $500 \mathrm{nM}$ to determine the optimal silencing conditions (data not shown). The addition of 250 or $500 \mathrm{nM}$ siRNA $\# 1$ or $\# 2$, respectively, resulted in $\sim 70 \%$ reduction of the amount of MCT1 expressed in the absence of siRNA or in the presence of an scrambled one (Figure 8A). Butyrate uptake measured in parallel wells was decreased in MCT1-silenced cells by 33 and $45 \%$ after transfection with siRNA $\# 1$ and $\# 2$ respectively (Figure $8 \mathrm{C}$ ).

In addition, MCT1 expression was analyzed in BCS-TC2 and BCS-TC2.BR2 cells under the experimental conditions described in Figure 6. MCT1 expression showed a similar behavior to butyrate uptake (Figure 6B\&C). No variation in MCT1 levels were detected with incubation time in the presence of $4 \mathrm{mM}$ butyrate in BCS-TC2.BR2 cells whereas BCS-TC2 cells showed a progressive increase (Figure 6C, left panel). Regarding the effect of 4 days incubation in the presence of increasing butyrate concentrations, BCS-TC2.BR2 cells showed no MCT1 variations up to $6 \mathrm{mM}$ while BCS-TC2 showed a sharp increase in expression at 2 and $4 \mathrm{mM}$ butyrate with a slower increase thereafter (Figure $6 \mathrm{C}$, right panel). 


\section{DISCUSSION}

Intestinal health and function are strongly dependent on appropriate levels of butyrate and other SCFAs in the colon lumen; concentration of SCFAs may reach around $100 \mathrm{mM}$ with a $20-30 \%$ butyrate [26]. Butyrate is taken up by colon epithelial cells and not only serves as a major source of energy for the colonic mucosa, but it also induces differentiation and apoptosis which may contribute to cancer prevention [2]. Butyrate prevents colonic mucosa inflammation [1] and infection by certain pathological bacteria as Shigella by induction of antimicrobial peptides as LL-37 [27]. The absence of butyrate in colonic tissue is associated with mucosal atrophy and colonocyte death. Many tumor cells are highly dependent on glycolysis, but glucose availability in colon tumor cells is significantly reduced and these cells are more dependent on butyrate as a fuel nutrient. In this context, understanding the mechanisms that govern butyrate transport acquires a remarkable role in cancer studies.

The study of butyrate transport in the colonocyte is complex due to: i) differences between apical and basolateral membranes of cells at the surface or at the colonic crypt (absent in transformed unpolarized cells), ii) marked differences between enterocytes from the proximal and distal colon, iii) species-specific differences in the transport of the ionized and protonated forms of SCFAs, and iv) the coexistence of multiple transport systems showing different substrate specificity or affinity. This scenario is even more complex in colorectal tumor cells.

Besides a diffusive unspecific monocarboxylate transport in cultured cells, a saturable transport with low affinity for butyrate (millimolar range) has been reported [28]. Here we describe for the first time that human colon adenocarcinoma cells present at least two different types of carrier-mediated butyrate transport mechanisms according to the kinetic parameters (affinity/capacity); a low-affinity/high-capacity transport system ( $K_{\mathrm{m}}$ around 100 $\mathrm{mM})$, and a high-affinity/low-capacity transport system ( $K_{\mathrm{m}}$ in the micromolar range). The existence of these two types of specific transport may have physiological and pathophysiological relevance. When butyrate concentration is high in the colonic lumen (e.g. after digestion of dietary fiber) the low-affinity/high-capacity system could become active. On the other hand, when butyrate concentration is low (e.g. in the intermeal interval, at the bottom of colonic crypts or in the inner layers of tumors) the high-affinity carrier-mediated transport could play an important role in cell survival. Previous reports in human colon adenoma (AA/C1) [29] and carcinoma (Caco-2) [19, 30] cells showed affinity constants in the millimolar range; however, here we demonstrate the existence of a high-affinity transport 
system that was not previously detected in these reports as they analyze butyrate transport at millimolar concentrations. Differences among the analyzed cell lines or the regulation of this transport mainly affected the $V_{\max }$, as described for the uptake regulation by butyrate in AA/C1 cells [29] or by PMA in Caco-2 cells [18]. This high-affinity transport is not only present in transformed cells, but we have also detected it in FHC cells that maintain the characteristics of normal human colonic cells [23, 31].

Which transporters might elicit the kinetically different carrier-mediated butyrate uptake mechanisms? According to data gathered from intestinal brush-border membrane vesicles [32] and Caco-2 cells [28], L-lactate and other monocarboxylates are transported through either proton-cotransporter or anion-antiporter mechanisms. We therefore studied the differential characteristics of the low- and the high-affinity components detected in the human colon adenocarcinoma cells. The low-affinity transport is only inhibited by butyrate analogues and bicarbonate, and is stimulated by DIDS. DIDS inhibition of anion exchangers from the AE family [8] can indirectly activate transport, as suggested by the bicarbonate inhibition of DIDS stimulation. Accordingly, a DIDS-insensitive butyrate-bicarbonate antiporter is likely to be responsible for low-affinity butyrate uptake. Among the low-affinity potential butyrate transporters, we have verified the expression of AE2 and MCT4 by RTPCR; however, AE2 monocarboxylate-exchange activity is inhibited by DIDS[8] and MCT4 is weakly expressed in Caco-2 cells. Thus, an additional butyrate-bicarbonate antiporter whose molecular identity is yet unknown must participate in the low-affinity butyrate uptake, as described in other systems [10, 28, 33].

The high-affinity component is inhibited by butyrate structural analogues, by 4-CHC and thiol group modifiers; it is insensitive to DIDS and is stimulated at acidic pH. These characteristics point to MCT1 as a promising candidate for this type of transport. Expression of MCT1 in Caco-2 cells has been reported, but associated to a low-affinity transport [13, 19, $28,30]$. We confirmed the expression of MCT1 in all of the cell lines, with the lowest expression seen in BCS-TC2 cells, which also showed the lowest transport. However, differences in uptake among the other cell lines only partially correlate with the levels of expression of this transporter or its ancillary protein CD147[34] suggesting the involvement of additional factors. Butyrate treatment enhanced MCT1 expression in non-tumorigenic human colon adenoma cells $(\mathrm{AA} / \mathrm{C} 1)$ [17, 29]. Here we have verified a time- and concentration-dependent up-regulation of MCT1 in BCS-TC2 cells concomitant with an increase in high-affinity transport, further supporting the role of MCT1. In BCS-TC2.BR2 cells, only concentrations higher than $6 \mathrm{mM}$ butyrate induce an increase in high-affinity 
transport along with higher MCT1 levels. The absence of effects at lower concentrations reflects the resistance of these cells to butyrate [22]. MCT1 involvement in high-affinity transport has been further confirmed by gene silencing using siRNAs. The reduction of MCT1 expression is accompanied by a significant decrease in uptake at low butyrate concentrations although not to the same extent. This effect is similar to that reported for human kidney HK-2 cells [24] reinforcing the notion that MCT1 plays a key role in highaffinity butyrate uptake, but additional factors may modulate this transport.

The high-affinity butyrate transport is $\mathrm{Na}^{+}$-dependent, but SLC5A8 and SLC5A12 $\mathrm{Na}^{+}$-monocarboxylate transporters are only expressed in Caco- 2 cells. Thus, inhibition of this transport may be related to the disappearance of the extracellular acidic microclimate adjacent to the membrane, maintained either by $\mathrm{Na}^{+}$-bicarbonate cotransporters [14] or $\mathrm{Na}^{+}-$ $\mathrm{H}^{+}$exchangers [35]. In fact, simultaneous inhibition of both systems partially impairs butyrate uptake. A proton gradient is required by MCT1 for its $\mathrm{H}^{+}$-monocarboxylate cotransport, which is maintained by an energy-dependent mechanism, emphasizing the influence of the cellular metabolic activity [36]. In addition, high-affinity butyrate transport is dependent on $\mathrm{PKC} \delta$ activity as specific activation or inhibition of this $\mathrm{PKC}$ isoform results in enhancement or reduction of uptake. In good agreement with these data, it has been described that butyrate modulates PKC $\delta$ in colon cancer cells [37] and that there is a link between PKC loss and a reduction in responsiveness of human adenocarcinoma tissues to apoptosis induced by butyrate [38].

The in vitro anti-tumorigenic effects of butyrate on colon cancer cells is well known but, in vivo, colon cancers grow despite the high butyrate concentration in the colonic lumen. Cancer cells must develop mechanisms to escape butyrate effects, including possible alterations in its uptake. Comparison of uptake in butyrate-resistant and sensitive cells only reveals minor differences regarding the effect of inhibitors, energy dependence, and signaling through PKC $\delta$. However, resistant cells show higher MCT1 and lower MCT4 expression, lack of response to butyrate treatment in high-affinity transport and MCT1 protein expression. These changes could also be related to a modification in the metabolism of the cells. Employing cDNA microarrays we have previously shown that the expression of some key glycolytic enzymes is modified in BCS-TC2.BR2 cells compared with parental BCS-TC2 cells [22].

In summary, we have described, for the first time, the presence of two components for specific butyrate uptake in colon adenocarcinoma cells that cooperate to enable its uptake at 
both high and low concentrations to maintain cell functionality. Low-affinity uptake is mediated by a butyrate-bicarbonate antiporter along with a possible contribution of AE2 and MCT4. The high-affinity/low-capacity activity, described and characterized here for the first time, is an energy- and $\mathrm{PKC} \delta$-dependent proton-monocarboxylate cotransport mainly mediated by MCT1. It functions under low butyrate concentrations and may be relevant for the survival of colon carcinoma cells in tumor regions with low glucose and butyrate availability. The physiological relevance of the high-affinity transport is confirmed by its presence in human normal colonic cells.

\section{ACKNOWLEDGEMENTS}

This work was supported by grants BMC2002-01407 and BFU2005-02671 from the Ministerio de Educación y Ciencia (Spain).

\section{REFERENCES}

1 Andoh, A., Tsujikawa, T. and Fujiyama, Y. (2003) Role of dietary fiber and short-chain fatty acids in the colon. Curr Pharm Des. 9, 347-358

2 Miller, S. J. (2004) Cellular and physiological effects of short-chain fatty acids. Mini Rev Med Chem. 4, 839-845

3 Myzak, M. C., Ho, E. and Dashwood, R. H. (2006) Dietary agents as histone deacetylase inhibitors. Molecular carcinogenesis. 45, 443-446

4 Soergel, K. H. (1994) Colonic fermentation: metabolic and clinical implications. Clin Investig. 72, 742-748

5 Krishnan, S., Rajendran, V. M. and Binder, H. J. (2003) Apical NHE isoforms differentially regulate butyrate-stimulated $\mathrm{Na}$ absorption in rat distal colon. Am J Physiol Cell Physiol. 285, C1246-C1254

6 Chu, S. and Montrose, M. H. (1996) Non-ionic diffusion and carrier-mediated transport drive extracellullar pH regulation of mouse colonic crypts. J Physiol. 494 ( Pt 3), 783793

7 Rajendran, V. M. and Binder, H. J. (2000) Characterization and molecular localization of anion transporters in colonic epithelial cells. Ann N Y Acad Sci. 915, 15-29 
8 Yabuuchi, H., Tamai, I., Sai, Y. and Tsuji, A. (1998) Possible role of anion exchanger AE2 as the intestinal monocarboxylic acid/anion antiporter. Pharm Res. 15, 411-416

9 Reynolds, D. A., Rajendran, V. M. and Binder, H. J. (1993) Bicarbonate-stimulated $[14 \mathrm{C}]$ butyrate uptake in basolateral membrane vesicles of rat distal colon. Gastroenterology. 105, 725-732

10 Tyagi, S., Venugopalakrishnan, J., Ramaswamy, K. and Dudeja, P. K. (2002) Mechanism of n-butyrate uptake in the human proximal colonic basolateral membranes. Am J Physiol Gastrointest Liver Physiol. 282, G676-G682

11 Halestrap, A. P. and Price, N. T. (1999) The proton-linked monocarboxylate transporter (MCT) family: structure, function and regulation. Biochem J. 343 Pt 2, 281-299

12 Enerson, B. E. and Drewes, L. R. (2003) Molecular features, regulation, and function of monocarboxylate transporters: implications for drug delivery. J Pharm Sci. 92, 15311544

13 Garcia, C. K., Goldstein, J. L., Pathak, R. K., Anderson, R. G. and Brown, M. S. (1994) Molecular characterization of a membrane transporter for lactate, pyruvate, and other monocarboxylates: implications for the Cori cycle. Cell. 76, 865-873

14 Becker, H. M., Broer, S. and Deitmer, J. W. (2004) Facilitated lactate transport by MCT1 when coexpressed with the sodium bicarbonate cotransporter (NBC) in Xenopus oocytes. Biophys J. 86, 235-247

15 Dimmer, K. S., Friedrich, B., Lang, F., Deitmer, J. W. and Broer, S. (2000) The lowaffinity monocarboxylate transporter MCT4 is adapted to the export of lactate in highly glycolytic cells. Biochem J. 350 Pt 1, 219-227

16 Srinivas, S. R., Gopal, E., Zhuang, L., Itagaki, S., Martin, P. M., Fei, Y. J., Ganapathy, V. and Prasad, P. D. (2005) Cloning and functional identification of slc5a12 as a sodiumcoupled low-affinity transporter for monocarboxylates (SMCT2). Biochem J. 392, 655664

17 Cuff, M., Dyer, J., Jones, M. and Shirazi-Beechey, S. (2005) The human colonic monocarboxylate transporter Isoform 1: its potential importance to colonic tissue homeostasis. Gastroenterology. 128, 676-686

18 Alrefai, W. A., Tyagi, S., Gill, R., Saksena, S., Hadjiagapiou, C., Mansour, F., Ramaswamy, K. and Dudeja, P. K. (2004) Regulation of butyrate uptake in Caco-2 cells by phorbol 12-myristate 13-acetate. Am J Physiol Gastrointest Liver Physiol. 286, G197203 
19 Hadjiagapiou, C., Schmidt, L., Dudeja, P. K., Layden, T. J. and Ramaswamy, K. (2000) Mechanism(s) of butyrate transport in Caco-2 cells: role of monocarboxylate transporter 1. Am J Physiol Gastrointest Liver Physiol. 279, G775-G780

20 Engle, M. J., Goetz, G. S. and Alpers, D. H. (1998) Caco-2 cells express a combination of colonocyte and enterocyte phenotypes. Journal of cellular physiology. 174, 362-369

21 Turnay, J., Olmo, N., Gavilanes, J. G., Benítez, J. and Lizarbe, M. A. (1990) Establishment and characterization of a new human colon adenocarcinoma cell line: BCS-TC2. Cytotechnology. 3, 75-88

22 López de Silanes, I., Olmo, N., Turnay, J., González de Buitrago, G., Pérez-Ramos, P., Guzmán-Aránguez, A., García-Díez, M., Lecona, E., Gorospe, M. and Lizarbe, M. A. (2004) Acquisition of resistance to butyrate enhances survival after stress and induces malignancy of human colon carcinoma cells. Cancer Res. 64, 4593-4600

23 Siddiqui, K. M. and Chopra, D. P. (1984) Primary and long term epithelial cell cultures from human fetal normal colonic mucosa. In vitro. 20, 859-868

24 Wang, Q., Lu, Y., Yuan, M., Darling, I. M., Repasky, E. A. and Morris, M. E. (2006) Characterization of monocarboxylate transport in human kidney HK-2 cells. Molecular pharmaceutics. 3, 675-685

25 Guzmán-Aránguez, A., Olmo, N., Turnay, J., Lecona, E., Pérez-Ramos, P., López de Silanes, I. and Lizarbe, M. A. (2005) Differentiation of human colon adenocarcinoma cells alters the expression and intracellular localization of annexins A1, A2, and A5. J Cell Biochem. 94, 178-193

26 Cummings, J. H. (1981) Short chain fatty acids in the human colon. Gut. 22, 763-779

27 Raqib, R., Sarker, P., Bergman, P., Ara, G., Lindh, M., Sack, D. A., Nasirul Islam, K. M., Gudmundsson, G. H., Andersson, J. and Agerberth, B. (2006) Improved outcome in shigellosis associated with butyrate induction of an endogenous peptide antibiotic. Proceedings of the National Academy of Sciences of the United States of America. 103, 9178-9183

28 Ogihara, T., Tamai, I. and Tsuji, A. (1999) Structural characterization of substrates for the anion exchange transporter in Caco-2 cells. J Pharm Sci. 88, 1217-1221

29 Cuff, M. A., Lambert, D. W. and Shirazi-Beechey, S. P. (2002) Substrate-induced regulation of the human colonic monocarboxylate transporter, MCT1. J Physiol. 539, $361-371$ 
30 Stein, J., Zores, M. and Schroder, O. (2000) Short-chain fatty acid (SCFA) uptake into Caco-2 cells by a pH-dependent and carrier mediated transport mechanism. Eur J Nutr. 39, $121-125$

31 Hofmanova, J., Zadak, Z., Hyspler, R., Mikeska, J., Zdansky, P., Vaculova, A., Netikova, J. and Kozubik, A. (2005) The effects of parenteral lipid emulsions on cancer and normal human colon epithelial cells in vitro. Physiological research / Academia Scientiarum Bohemoslovaca. 54, 409-418

32 Tamai, I., Ogihara, T., Takanaga, H., Maeda, H. and Tsuji, A. (2000) Anion antiport mechanism is involved in transport of lactic acid across intestinal epithelial brush-border membrane. Biochim Biophys Acta. 1468, 285-292

33 Vidyasagar, S., Barmeyer, C., Geibel, J., Binder, H. J. and Rajendran, V. M. (2005) Role of short-chain fatty acids in colonic $\mathrm{HCO}(3)$ secretion. Am J Physiol Gastrointest Liver Physiol. 288, G1217-G1226

34 Kirk, P., Wilson, M. C., Heddle, C., Brown, M. H., Barclay, A. N. and Halestrap, A. P. (2000) CD147 is tightly associated with lactate transporters MCT1 and MCT4 and facilitates their cell surface expression. Embo J. 19, 3896-3904

35 Martín-Venegas, R., Rodríguez-Lagunas, M. J., Geraert, P. A. and Ferrer, R. (2007) Monocarboxylate transporter 1 mediates DL-2-Hydroxy-(4-methylthio)butanoic acid transport across the apical membrane of Caco-2 cell monolayers. The Journal of nutrition. 137, 49-54

36 Gabel, G., Muller, F., Pfannkuche, H. and Aschenbach, J. R. (2001) Influence of isoform and DNP on butyrate transport across the sheep ruminal epithelium. J Comp Physiol [B]. 171, 215-221

37 McMillan, L., Butcher, S. K., Pongracz, J. and Lord, J. M. (2003) Opposing effects of butyrate and bile acids on apoptosis of human colon adenoma cells: differential activation of PKC and MAP kinases. Br J Cancer. 88, 748-753

38 Craven, P. A. and DeRubertis, F. R. (1994) Loss of protein kinase C delta isozyme immunoreactivity in human adenocarcinomas. Dig Dis Sci. 39, 481-489 
Table 1 Primers used for RT-PCR analysis

\begin{tabular}{|c|c|c|c|}
\hline $\begin{array}{l}\text { Protein / gene } \\
\text { (accession number) }\end{array}$ & Primer sequence & Position & $\begin{array}{l}\text { Expected } \\
\text { size (bp) }\end{array}$ \\
\hline MCT1 / SLC16A1 & Forward: 5'-GGAAGGTGGACCAGAATGAA-3' & $3038-3057$ & \\
\hline (NM_003051) & Reverse: 5'-CAATTTAGCAAGGCCCAAAA-3' & $3323-3304$ & 286 \\
\hline MCT4 / SLC16A3 & Forward: 5'-GACACAGCCTGGATCTCCTC-3 & $237-256$ & \\
\hline (NM_004207) & Reverse: 5'-GAAGACAGGGCTACCTGCTG-3' & $539-520$ & 303 \\
\hline AE2 / SLC4A2 & Forward: 5'-GCTGGGAGAGAAGACACAGG-3' & $2361-2380$ & \\
\hline (NM_003040) & Reverse: 5'-CGAAGATCTCCTGGGTGAAG-3' & $2656-2637$ & 296 \\
\hline SLC5A8 & Forward: 5'-CCCTATCAGTCCAGGGCATA-3 & $2700-2789$ & \\
\hline (NM_145913) & Reverse: 5'-CCCAGGGCAATAAACAGAAA-3' & 2998-2979 & 299 \\
\hline SLC5A12 & Forward: 5'-TGTGGGCTTCTTAACGGTTC-3' & $864-883$ & \\
\hline (NM_178498) & Reverse: 5'-AGCTGGTCTGGTGCTGAGAT-3' & $1238-1219$ & 375 \\
\hline CD147 / BSG & Forward: 5'-GCAGGTTCTTCGTGAGTTCC-3' & $655-674$ & \\
\hline (NM_198590) & Reverse: 5'-GCCTTTGTCATTCTGGTGCT-3' & $968-949$ & 314 \\
\hline GAPDH & Forward: 5'- GAAGGTGAAGGTCGGAGTC -3' & $81-99$ & \\
\hline (NM_002046) & Reverse: 5'-GAAGATGGTGATGGGATTTC -3' & $306-287$ & 226 \\
\hline
\end{tabular}


Table 2 Kinetic parameters of the high-affinity/low-capacity $\left[{ }^{14} \mathrm{C}\right]$ butyrate transport and phosphatase alkaline activity in human colon adenocarcinoma cells

\begin{tabular}{|c|c|c|c|}
\hline Cell line & $\begin{array}{c}V_{\max } \times 10^{4} \\
\left(\mathrm{nmol} \cdot \mu \mathrm{g}^{-1} \cdot \min ^{-1}\right)\end{array}$ & $\begin{array}{c}K_{\mathrm{m}} \\
(\mu \mathrm{M})\end{array}$ & $\begin{array}{l}\operatorname{ALP} \operatorname{activity}\left({ }^{\mathrm{a}}\right) \\
(\mathrm{mU} / \mathrm{mg})\end{array}$ \\
\hline$\overline{\mathrm{BCS}-\mathrm{TC} 2}$ & $0.71 \pm 0.04$ & $17.9 \pm 4.0$ & $27.3 \pm 1.3$ \\
\hline BCS-TC2.BR2 & $0.99 \pm 0.06$ & $14.0 \pm 3.6$ & $65.8 \pm 2.6$ \\
\hline HT-29 & $2.93 \pm 0.11$ & $13.9 \pm 2.5$ & $6.8 \pm 0.8$ \\
\hline Caco-2 & $4.70 \pm 0.18$ & $23.0 \pm 3.6$ & $162.0 \pm 2.7$ \\
\hline FHC & $3.42 \pm 0.22$ & $14.5 \pm 4.9$ & $466.0 \pm 18.1$ \\
\hline
\end{tabular}

(a) Alkaline phosphatase (ALP) activity was determined in the same conditions as butyrate uptake. 


\section{FIGURE LEGENDS}

Figure 1 Kinetics of $\left[{ }^{14} \mathrm{C}\right]$ butyrate uptake and effect of different agents in BCS-TC2 cells.

Measurement of butyrate transport at $10-150 \mathrm{mM}$ butyrate. (A) Butyrate transport at $37^{\circ} \mathrm{C}$ (black circles) and $4^{\circ} \mathrm{C}$ (white circles). Discontinuous lines represent the nonlinear regression of data at $37^{\circ} \mathrm{C}$ showing a hyperbolic and a linear component. (B) Effect of structural analogues, inhibitors and ions on butyrate uptake. Cells were preincubated at the indicated agent concentration or in sodium-free buffer $\left(-\mathrm{Na}^{+}\right)$for $15 \mathrm{~min}$ before measuring uptake in the presence of $20 \mathrm{mM}$ butyrate. Data represent specific uptake expressed as a percentage of the control uptake; data are the mean $\pm \mathrm{SD}$ of four independent experiments with triplicate samples $(* * p<0.01)$.

Figure 2 Kinetics of $\left[{ }^{14} \mathrm{C}\right]$ butyrate uptake and effect of $\mathrm{pH}$ and different agents in BCSTC2 cells at low butyrate concentrations.

Experiments were essentially performed as indicated in Figure 1. (A) Butyrate transport at $37^{\circ} \mathrm{C}$ (black circles) is shown at concentrations below $200 \mu \mathrm{M}$ or $5 \mathrm{mM}$ (inset). Discontinuous lines represent the nonlinear regression of data showing the hyperbolic and linear components. (B) Effect of $\mathrm{pH}$ on butyrate uptake at $40 \mu \mathrm{M}$ butyrate. (C) Effect of structural analogues, inhibitors and ions on butyrate uptake. Data represent specific uptake and are expressed as percentage of the control; values in the presence of inhibitors were significantly lower than the control $(p<0.01)$ with the exception of mannitol and DIDS; data are the mean \pm SD of four independent experiments with triplicate samples.

Figure 3 Kinetics of $\left[{ }^{14} \mathrm{C}\right]$ butyrate uptake in human colon adenocarcinoma cells and human normal colon cells at low butyrate concentrations.

Experiments were essentially performed as indicated in Figure 1 . Butyrate transport at $37^{\circ} \mathrm{C}$ is shown at concentrations below $5 \mathrm{mM}$ (A) or $200 \mu \mathrm{M}$ (B) in human colon adenocarcinoma cells. (C) Butyrate transport in normal colonic cells (FHC) at concentrations below $200 \mu \mathrm{M}$ or $5 \mathrm{mM}$ (inset). Discontinuous lines represent the nonlinear regression of data showing the hyperbolic and linear components. In all the cases, kinetic parameters determined from the 
saturable hyperbolic components are shown in Table 2. Data are the mean $\pm \mathrm{SD}$ of four independent experiments with triplicate samples.

Figure 4 Effect of different agents on $\left[{ }^{14} \mathrm{C}\right]$ butyrate uptake in butyrate-resistant BCS-TC2.BR2 cells.

Uptake assays were carried out at $20 \mathrm{mM}$ (A) and $40 \mu \mathrm{M}$ (B) butyrate after preincubation with the indicated agent or in sodium-free buffer $\left(-\mathrm{Na}^{+}\right)$for $15 \mathrm{~min}$. Data represent specific uptake and are expressed as percentage of the control; data are the mean $\pm \mathrm{SD}$ of four independent experiments with triplicate samples $\left({ }^{*} p<0.05,{ }^{*} p<0.01\right)$.

Figure 5 Energy requirement and effect of PKC inhibitors and activators in $\left[{ }^{14} \mathrm{C}\right]$ butyrate uptake in butyrate-sensitive and resistant cells.

Specific uptake at $40 \mu \mathrm{M}$ butyrate was analyzed after 15 min preincubation in the presence of the indicated concentrations of antimycin A, rottlerin, BSM, PMA and ingenol-3-angelate (I3A). Data are expressed as percentage of control uptake in the absence of these agents and are the mean $\pm \mathrm{SD}$ of three independent experiments with triplicate samples $\left({ }^{*} p<0.05\right.$, $* * p<0.01)$.

Figure 6 Effect of butyrate treatment in its uptake and MCT1 expression in butyratesensitive and resistant cells.

(A) Specific uptake was analyzed in BCS-TC2 (black circles) and BCS-TC2.BR2 cells (white circles) after preincubation (left panel) up to 4 days in the presence of $4 \mathrm{mM}$ butyrate or (right panel) after 4-day treatment with up to $10 \mathrm{mM}$ butyrate. Data are expressed as percentage of specific uptake after preincubation in the absence of butyrate, and correspond to mean values $\pm \mathrm{SD}$ of three independent experiments with triplicate samples. (B) Representative Western blots corresponding to MCT1 expression under the experimental conditions described in (A). Vinculin expression is also shown. (C) Densitometric analysis of MCT1 levels using vinculin expression for normalization. Data correspond to mean values \pm SD of four independent experiments.

\section{Figure 7 Expression of different transporters in human colon adenocarcinoma cells.}

RT-PCR analysis of transporters potentially involved in butyrate uptake in colon adenocarcinoma cells; glyceraldehyde 3-phosphate dehydrogenase (GAPDH) was used as control. The number of PCR cycles is indicated. 


\section{Figure 8 MCT1 silencing using specific siRNAs and influence on $\left[{ }^{14} \mathrm{C}\right]$ butyrate uptake} in BCS-TC2 cells.

(A) BCS-TC2 cells were transfected with $500 \mathrm{nM}$ scrambled siRNA (S) or with $250 \mathrm{nM}$ or $500 \mathrm{nM}$ siRNA \#1 (si1) or \#2 (si2), respectively. $72 \mathrm{~h}$ after transfection, cells were homogenized and analyzed by Western blot using MCT1 or vinculin specific antibodies. Representative blots are shown. (B) Densitometric analysis of MCT1 levels using vinculin expression for normalization. Data correspond to mean values \pm SD of four independent experiments. (C) Specific transport at $40 \mu \mathrm{M}$ butyrate was analyzed in parallel untransfected and transfected cultures. Data correspond to mean values $\pm \mathrm{SD}$ of three independent experiments using triplicate samples. 
Figure 1
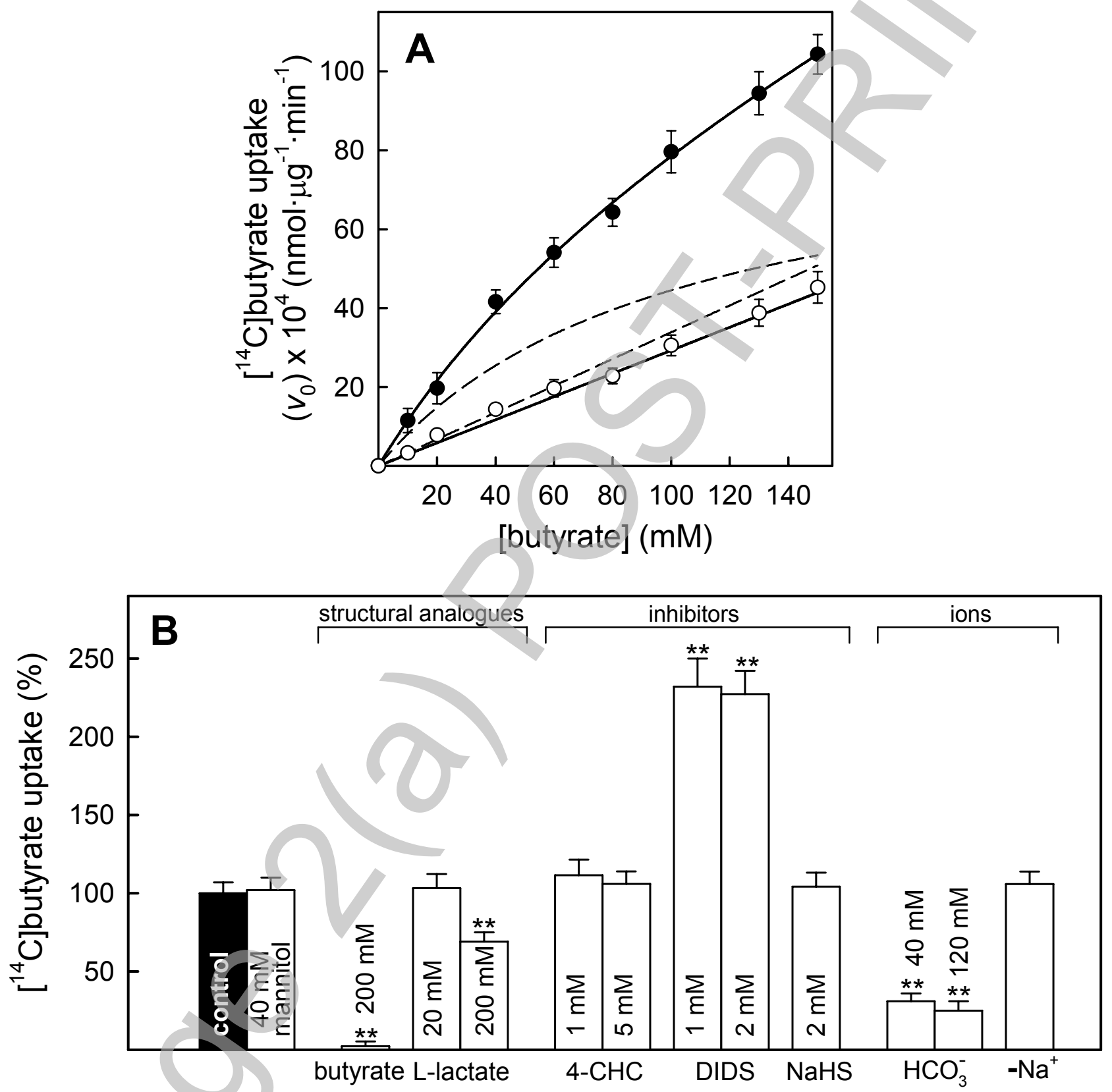

Licenced copy. Copying is not permitted, except with prior permission and as allowed by law. (C) 2007 The Authors Journal compilation (C) 2007 Biochemical Society 


\section{Figure 2}
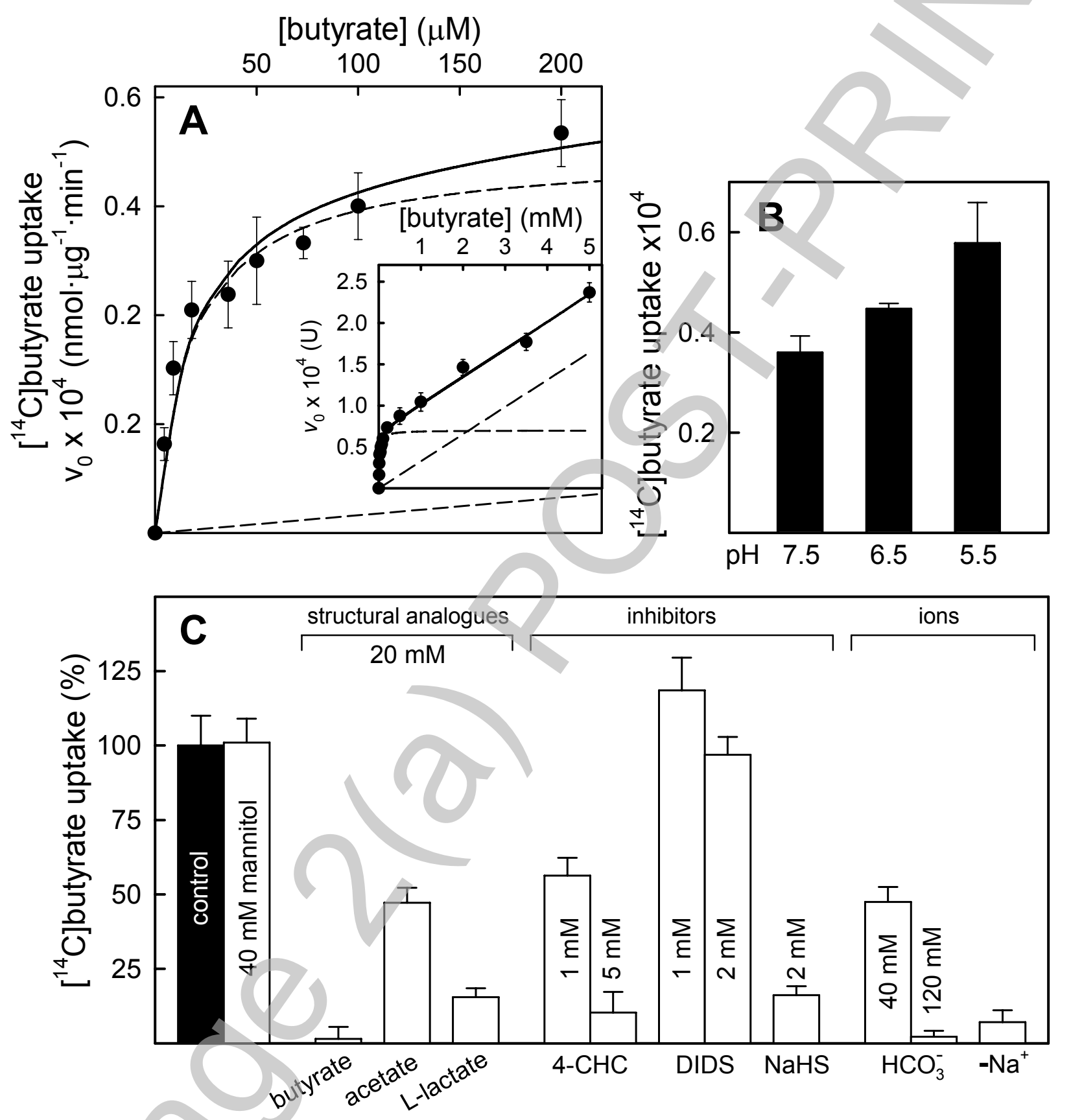

Licenced copy. Copying is not permitted, except with prior permission and as allowed by law. 
Figure 3

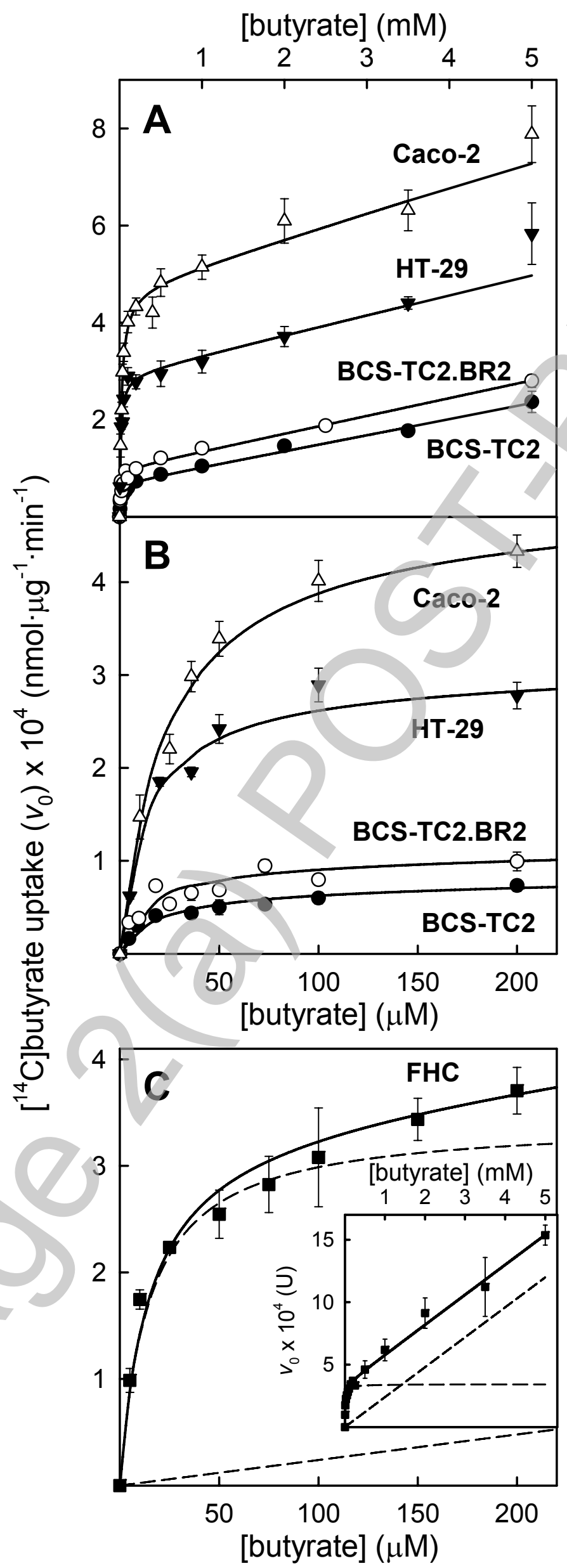

Licenced copy. Copying is not permitted, except with prior permission and as allowed by law. (C) 2007 The Authors Journal compilation (C) 2007 Biochemical Society 


\section{Figure 4}
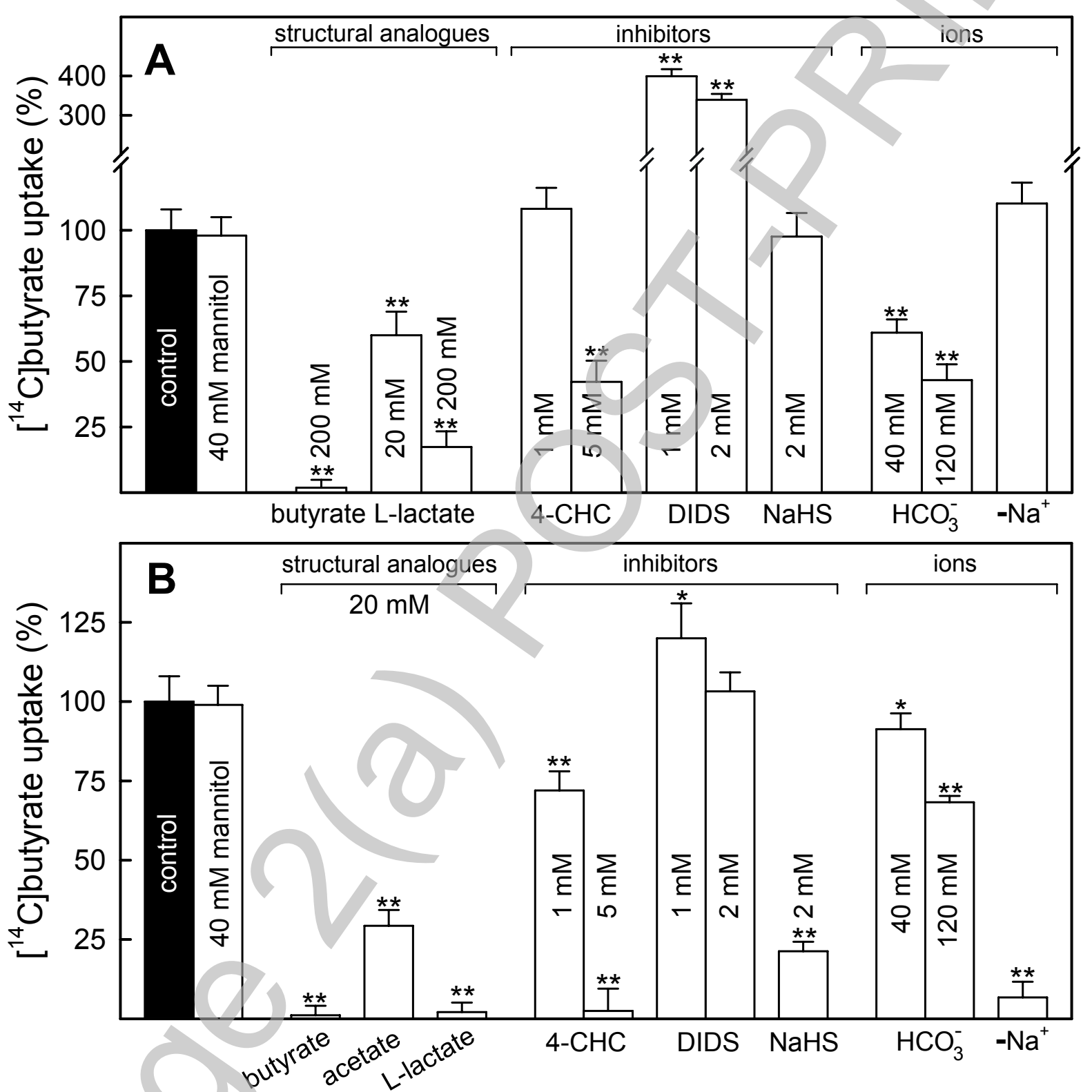


\section{Figure 5}

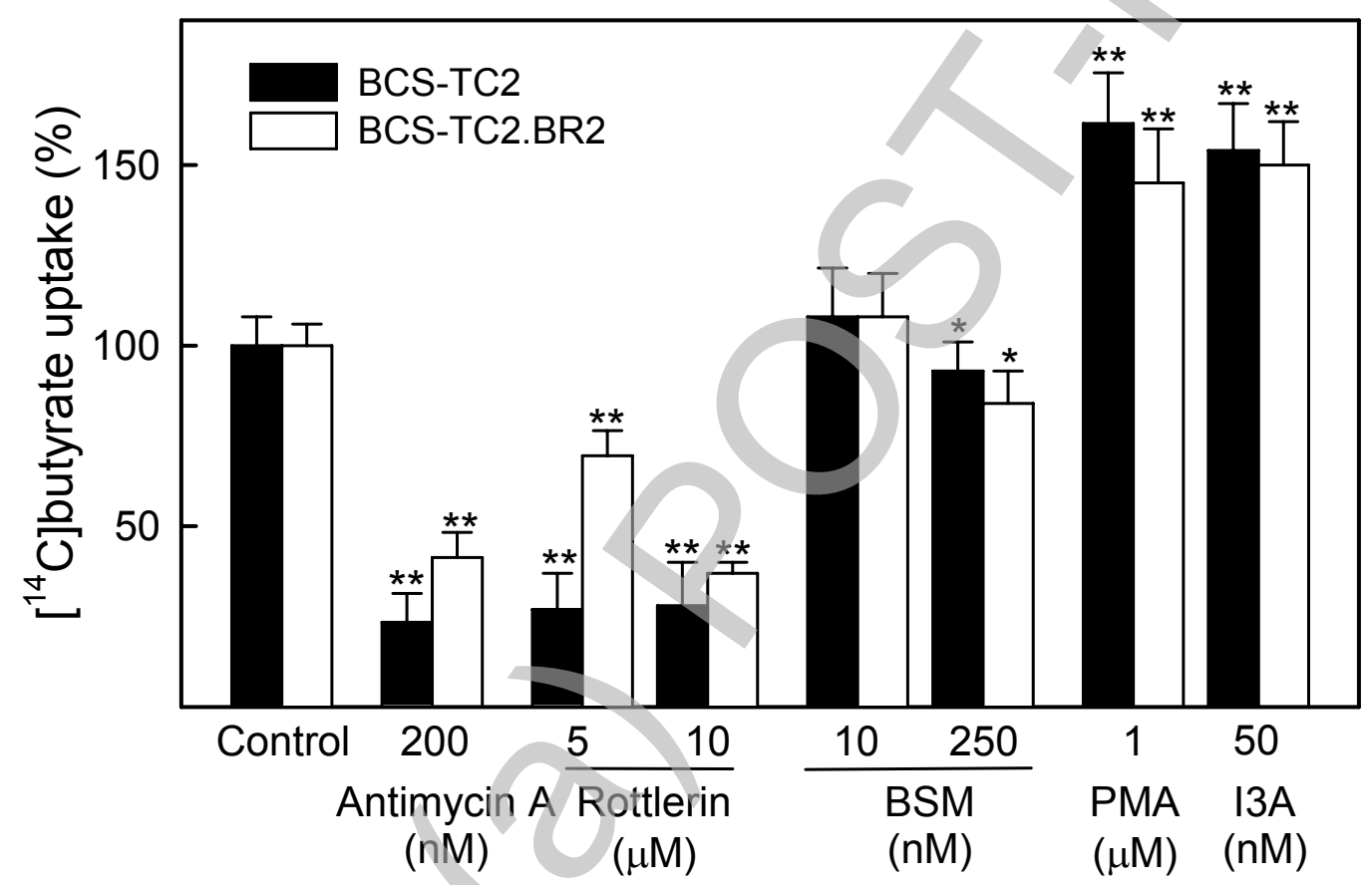

Licenced copy. Copying is not permitted, except with prior permission and as allowed by law. (C) 2007 The Authors Journal compilation (C) 2007 Biochemical Society 
Figure 6

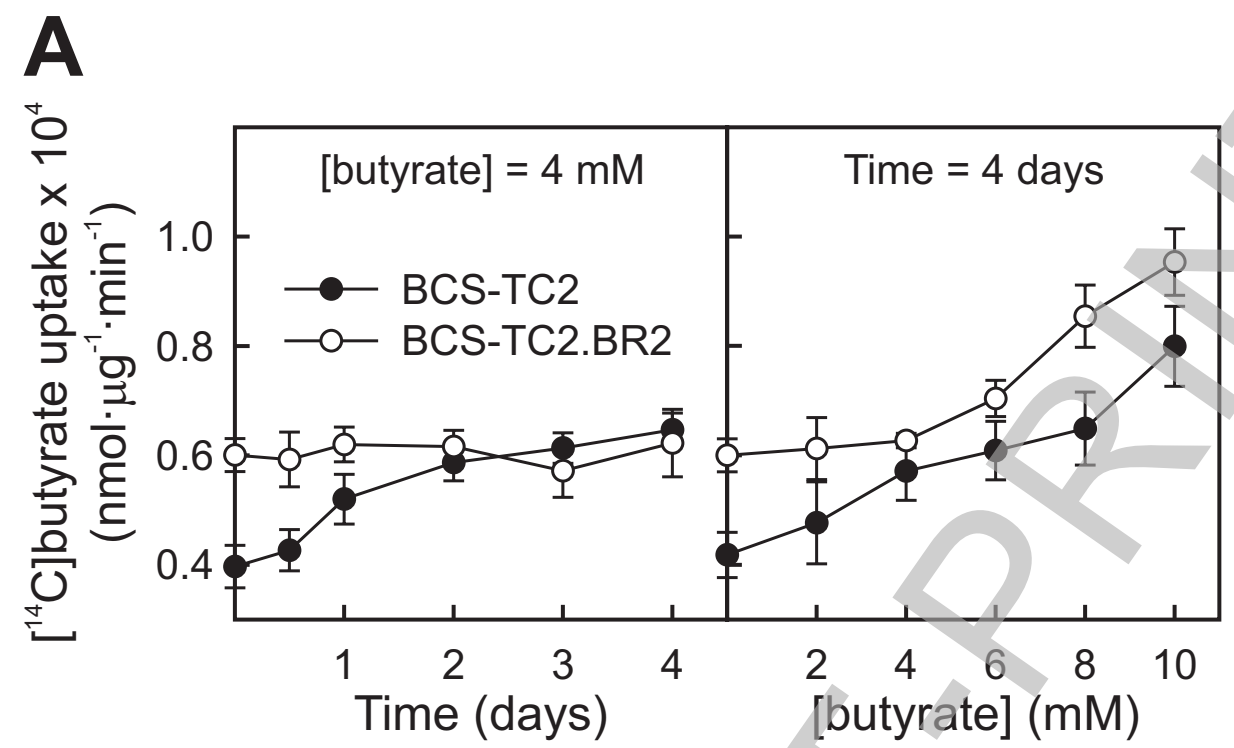

B

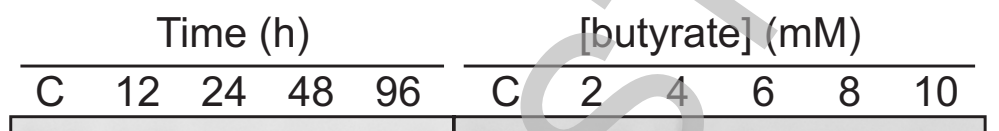

MCT1

Vin

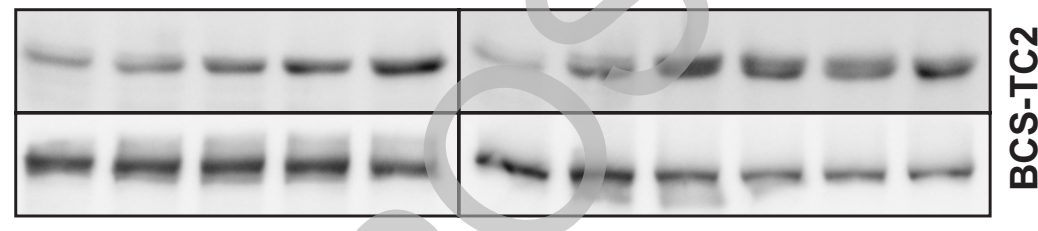

MCT1
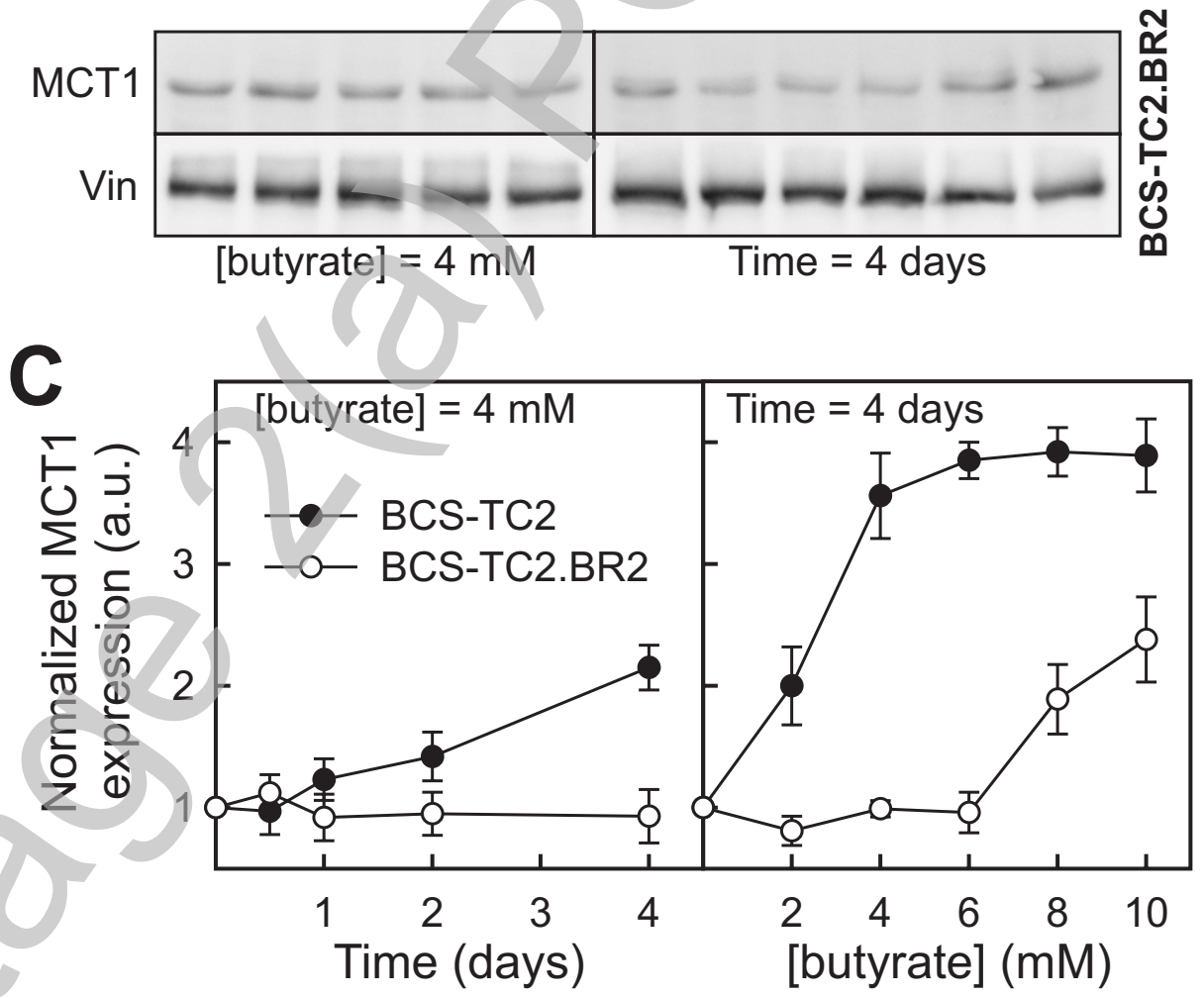

Licenced copy. Copying is not permitted, except with prior permission and as allowed by law. (c) 2007 The Authors Journal compilation (c) 2007 Biochemical Society 


\section{Figure 7}
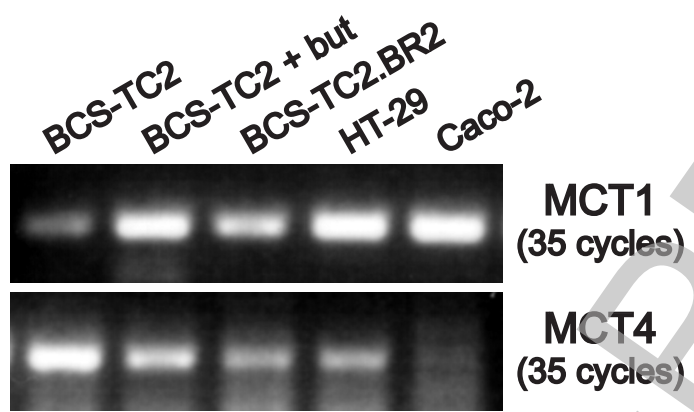

MCT4

(35 cycles)

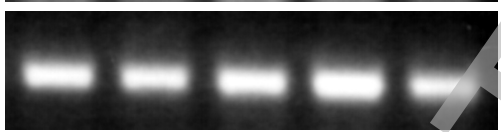

AE2

(32 cycles)

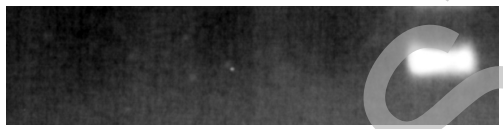

SLC5A8

(40 cycles)

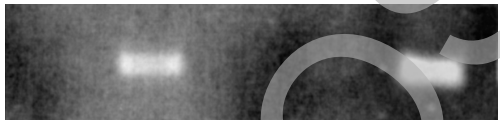

SLC5A12

(40 cycles)

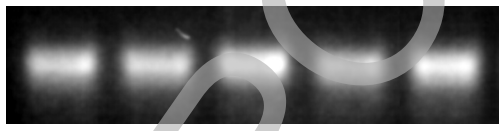

CD147

(27 cycles)

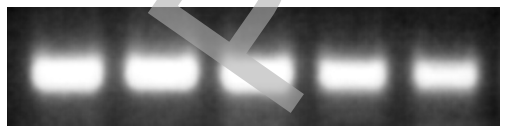

GAPDH

(27 cycles) 


\section{Figure 8}

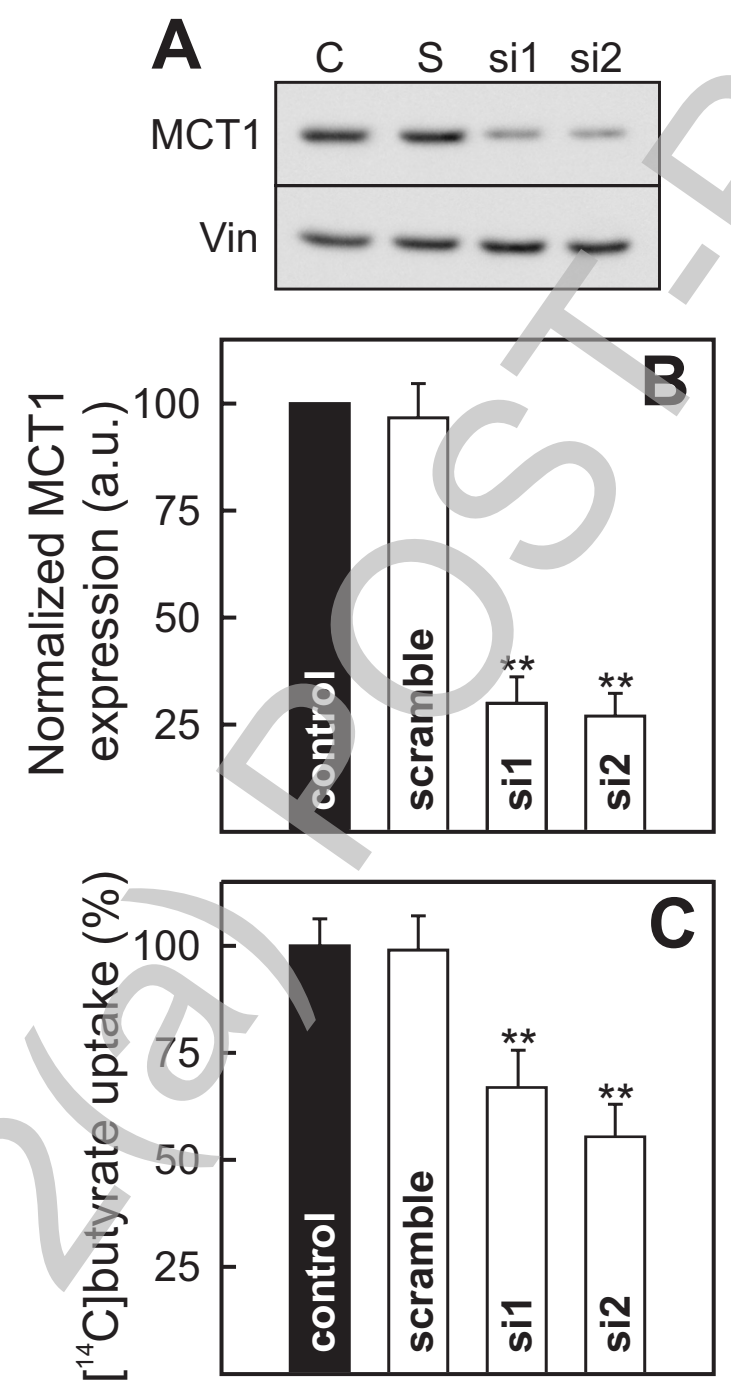

